\title{
EDITORIAL
}

\section{Internationalization of higher education and Islamization of Knowledge}

\section{Ssekamanya Siraje Abdallah ${ }^{\mathrm{a}}$}

Internationalization has become one of the most common word associated with higher education. In the increasingly competitive higher education marketplace, internationalization is one of the special distinguishing features of institutions. This is especially so when institutions are seeking for extra points in the global and regional rankings.

Interestingly, the original model of higher education created in the Islamic centers of higher learning in Iraq, the Levant (al-Sham), Egypt, the Maghreb, and Andalusia was international, if it is judged by today's standards. Educational institutions were microcosms of the global Islamic Ummah. Some institutions of higher learning in Andalusia and Sicilia had nonMuslim students. For Muslim institutions of higher learning to successfully participate in today's competition for dominance in the global education market, they need to revive the ummatic outlook of the early institutions of the Muslim world.

This volume of IJES includes a number of papers discussing the pertinent issue of internationalization of higher

a Kulliyyah of Education, International Islamic University Malaysia. 
education from various dimensions.

Aref Al-Atari's paper provides a firm grounding in the topic of internationalization of higher education. The author reviews the history of internationalization of higher education all the way from the Greek civilization, through the Arab-Islamic institutions of the middle-ages, until today's globalization of higher education and the practice of institutional ranking. Looking specifically at institutions of higher education in the Arab states, Al-Atari proposes a model of internationalization of higher education without the accompanying "de-contextualization". In other words, his model shows how institutions can effectively play the globalization game without losing their local character and national identity.

The second paper, by Abdul Qahar Sarwari and Nubli Wahab, considers a specific issue within the international education process. While many institutions of higher education pride themselves of having international students from dozens and sometimes hundreds of countries around the world, the same institutions are increasingly complaining of the difficulty of attracting new international students. Using the "low hanging fruit first" paradigm, the authors propose that institutions consider using existing international students, especially those at the postgraduate level, as goodwill ambassadors to attract new students from their home countries. Such students are specially equipped for this task, since they understand both their host counties and their home countries. This presupposes, however, that they had positive experiences at their host institutions. indirectly, the paper reminds host institutions to put systems and procedures in place for providing their international students with positive experiences, if they are to effectively play their ambassadorial role. 
In Muslim societies today, internationalization goes hand in hand with Islamization. The next two papers deal with the challenges of Islamization of knowledge in a predominantly Muslim country.

While there have been many conceptual and empirical studies on the need for and actual experiences of Islamization of knowledge at different levels of education in the Muslim world, many pertinent questions are often pass over in silence. One of the neglected questions is: who should Islamize? Saheed Ahmad Rufai considers this important question by considering the various calls for the integration or Islamization of the curricula of different academic disciplines. He argues that as a technical area, curriculum development has its standards and procedures. for anyone to effectively design, develop or change a curriculum, he must have the requisite knowledge and experience in that field. Thus attempts to Islamize the curricula of various educational disciplines face a double challenge. The integrators must not only be conversant with the Islamic principles relevant to the area in question, but also have expert knowledge in the discipline they want to Islamize and a good grasp of the principles and practice of curriculum development. Without these, the outcome would be "unsystematic Islamization."

Continuing with the challenges of Islamization, Rafiu Ibrahim Adebayo outlines the stumbling blocks faced by private Islamic universities in Nigeria in their efforts to institutionalize Islamization of knowledge. While there is a consensus among leaders and academics at those institutions regarding the necessity of Islamization of knowledge, the actual implementation of that agenda is very complicated. Among the key challenges discussed are lack of a universally accepted model of Islamization, shortage of qualified faculty, lack of interest among students, and language barriers. Clearly, these challenges are not unlike what has been 
encountered by similar Institutions in other parts of the Muslim world.

Some of the means to overcome the above challenges have been with us for almost a millennium, albeit unnoticed. Siti Noor Fauziah Abd Rahim discusses some of the lessons Muslim educators today can learn from the successful integration of Islamic spiritual disciplines with eastern and western philosophies in the work of the great spiritual master, Mawlana Jalal al-Din al-Rumi. Among al-Rumi's major contributions that teachers can implement in their classrooms include taking God-consciousness as the foundation of learning, instilling love and compassion among learners through service learning, making learning enjoyable, and emphasizing real-world experiential learning.

On the issue of pedagogy and integration of knowledge, Jamiu Abdur-Rafiu and Y. A. Fasasi report an experiment they conducted to determine the effect of using the instructional method of concept-mapping on students' achievement in Islamic studies. The new approach had a positive impact, showing the need for Islamic studies teachers to use new approaches in delivering their lessons.

The last paper by Wan Mazwati Wan Yusoff and Norwati Mansor continues with the discussion of the nexus between pedagogy and Islamic education. They explored the strategies used by teachers to deal with disruptive classroom behaviors at an Islamic religious school in Malaysia. Among the findings were that while student disruptions were generally low-level misdemeanours, they were both burdensome and frustrating for the teachers. Unfortunately, teachers often took the common punitive measures. Apparently, someone has to promote al-Rumi's pedagogy to them. 
The final paper in this volume is a book review by Abdulmajid Aldaba who reviews Rosnani Hashim and Mina Hattori's Critical Issues in Muslim Higher Education. The issues discussed in this edited book foreshadow the contents of this volume of IJES. It is indeed a worthwhile addition to studies on higher education, especially in the Muslim world. 